\title{
The Effect of Trade Openness on Income Inequality with the Role of
} Institutional Quality

\author{
Lim Thye Goh ${ }^{1 *}$, Siong Hook Law ${ }^{2}$ \\ ${ }^{1}$ Inti International College Subang Malaysia, ${ }^{2}$ Universiti Putra Malaysia \\ * limthye.goh@newinti.edu.my
}

\begin{tabular}{ll}
\hline Article Info & Abstract \\
\hline $\begin{array}{l}\text { Received }: 2019-04-21 \\
\text { Accepted }: 2019-07-11\end{array}$ & $\begin{array}{l}\text { This study investigates the effect of trade openness on income } \\
\text { inequality using the panel system generalised method of moments } \\
\text { Published }: 2019-07-28\end{array}$ \\
\hline $\begin{array}{l}\text { (GMM). The sample countries consist of 65 developed and } \\
\text { developing countries and the time period covers from 1984 to 2012. } \\
\text { Keywords: trade openness, } \\
\text { income inequality, institutional } \\
\text { quality, system GMM }\end{array}$ & $\begin{array}{l}\text { institutional quality in influencing the effectof trade openness on } \\
\text { income inequality. The empirical results reveal that trade openness } \\
\text { tends to increase income inequality. In addition, the marginal effect } \\
\text { also revealed that institutional quality has a corrective effect on the } \\
\text { trade openness - income inequality nexus. }\end{array}$ \\
\hline
\end{tabular}

\section{Introduction}

The dynamic advantages of trade openness on the positive growth oftrade have always been discussed and highlighted by policy makers, they include increased exports, job opportunities and most importantly economic growth (WTO, 2007). Although trade openness might generate substantial economic benefits (Dimitrova and Lakatos, 2014), it does not guarantee that those benefits will be evenly distributed. Thus, trade openness will further dampen income inequality should those benefits beunevenly distributed (United Nations Conference on Trade and Development (UNCTAD), 2012). According to the United Nations Development Programme report (UNDP) (1999), the top fifth of the world's people in the richest countries enjoy 82 percent of the expanding export trade and 68 percent of foreign direct investment and the bottom fifth, enjoy barely more than 1 percent of export trade and foreign direct investment respectively. This implies that whilst trade openness promotes economic integration it says nothing about income distribution parity.

Earlier literature predicts that trade will lead to a rise in the return on the abundant factor in a country, whilst simultaneously causinga fall in the return of the scarce factor (Stolper, 1941). Thus, for developing countries with an abundant supply of labour, trade openness will lead to an increase in wages leading to a decrease in inequality. On the other hand, for developed countries with an abundant supply of skilled labour, trade openness will lead to an increase in the income of the skilled labour force and consequently widening income inequality. The theoretical argument, hence, contradicts with the reality, where UNCTAD (1994) indicated that in general, income inequality rises after trade openness. It was reported that one of the reasons this increase occurs is through the importation of technology which raises the returns to skilled labour and reduces the demand for unskilled labour.

The continuous efforts of the World Trade Organisation (WTO) to fight for no boundaries and discrimination between its trading partners has encouraged many researchers to investigate the chain effects of trade openness on income distribution (see for example, 
Ravallion and Jayasuriya, 1988; Glewwe, 1988; Carneiro and Arbache, 2003; Agenor, 2004; Meschi and Vivarelli, 2008; Roses, Galarraga and Tirado, 2010; Mah, 2013).

This study examines the effect of trade openness on income inequality. We also intend to describethe roles of institutions in moderating the trade openness-income inequality nexus (UNDP, 1999). Since North (1991) introduced the concept of institutions, it has received great attention in existing literature. According to North (1991), institutions can be defined as the human-devised constraints that structure political, economic and social interaction.

Institutions are important because they provide the incentive structure for an economy, shape the direction of economic changes toward growth, stagnation or decline. Thus, it is widely believed that poor institutional quality has a detrimental effect on income distribution.

This study contributes to the existing literature in three important aspects. Firstly, this study uses international data that consists of both developed and developing countries that allow policy makers to evaluate the impact of trade openness on income inequality. Second, this study incorporates the role of institutional quality in influencing the trade openness-income inequality relation. In other words, we intend to describe the roles of institutional quality in moderating the trade openness-income inequality nexus. Lastly, we use the institutional quality variable as an interactive term in the multiplicative model, highlighting the marginal effect of trade openness on income inequality when institutional quality is present.

The remainder of this paper is structured as follows: Section 2.0 reviews the literature concerning trade openness and income inequality. Section 3.0 presents an empirical model and explains the estimation techniques. Section 4.0 discusses the empirical results and robustness checks. Section 5.0 provides the summary and conclusions.

\section{A Review of Related Literature}

Recent research studies have illustratedambiguous findings on the trade openness - income inequalityrelationship. The World Trade Organization (WTO) largely pursues the idea that to reduces obstacles to trade, where trade openness contributes to economic growth and development. However, earlier research by Stolper and Samuelson (1941) suggested that such changes are unlikely to happen in practice. From the basis of the Heckscher-Ohlin model developed in the 1930s, Stolper and Samuelson pointed out that trade will lead to a rise in the real wages of the abundant factor and a drop in the real wages of the scarce factor. Hence, trade always involves trading off between gains for some and losses for others. The implication of the finding was that trade will lead to a reduction in income inequality in developing countries and an increase in income inequality in developed countries. Suggesting there is a significant tradeoff between trade openness and income distribution.

Several empirical studies have been undertaken to investigate the impact of trade openness on income distribution. However, the finding ofstudies has not resulted in consensus. Some authors have found evidence that supported the Stolper-Samuelson theorem. For instance, Savvides (1998) and Dollar and Kraay (2004) pointed out that income inequality declines after trade openness in developing countries. In addition, they suggested that globalisation which started in the 1980s promotes economic equality and reduced poverty, their empirical findings also pointed out that economic growth and human capital accumulation is found to have an equalising effect on income distribution for both developed and developing countries.

Based on World Bank data from 1960 -1999, Wade (2004) argued that globalisation in the context of the world regime generates more mutual benefit than conflicting interest. His finding suggested that the rising economic integration across national borders improves world poverty and the income inequality level. In addition, Mohammad (1981) examined the income 
redistribution effects in India from a trade promotion perspective. He found that trade openness significantly increased the total employment and income level for export-led industry thus improving the income distribution. However,the import-led industry seems to be less favourable to the growth of employment and income. This finding is, however, in parallel with the Stolper and Samuelsson (1941) theorem that, India (developing country) with abundant labour benefited from export-led industry.

On the other hand, a large amount of research has highlighted that trade openness is found to dampen equality in income distribution. Taking one of the examples, Roses, Galarraga and Tirado (2010) investigated the evolution of Spanish regional income inequality from 1860 1930 and concluded that regional income inequality in Spain increased substantially during the initial phases of globalisation, growth and industrialisation. Thus, suggesting that trade openness is detrimental to income distribution. Similarly, Borras (2007) pointed out that although trade openness had led to an increase of production in the agricultural sector, local farmers were unable to compete with imports from neighbouring countries, thus, trade opennessnot only failed to improve the standard of living in the Philippines but actually increased poverty and income inequality. In addition, Dutt and Mukhopadhyay (2005) analysed the correlation between globalisation and income inequality in developing nations over the period of 1977 - 1998 . Empirically the authors concluded that trade and capital flow caused a reduction in real wages and increased income inequality.

Although trade policy reforms during the 1990s resulted in an increase in trade volume and wealth for many countries. It did not promote a fair distribution of wealth. Mah (2003) found that income inequality, national income per capita and trade openness are significantly cointegrated in Korea. The finding of his research indicated that trade openness income inequality in Korea. Ackah (2007) acknowledged that although trade openness increased trade volumes in Ghana, it resulted in an increase in poverty and income inequality among the rural labour households. In addition, the positive effect of protection is disproportionately greater for low-skilled labour households which suggested that a depletion of welfare for unskilled labour households may be caused by trade openness. Thus, when nations are contemplating trade opennessitshould be complemented by human capital investment. On the other hand, Mah (2013) who analysed the effect of globalisation upon China over the period of 1986 - 2006, pointed out that trade openness had a strong positive effect on income inequality in China. Thus, in conclusion, the progress of globalisation worsened the situation of income inequality in the case of Korea, Ghana and China.

Aradhyula, Rahman and Seenivasan (2007) utilised a two-stage least square regression model on panel data of 21 developed and 23 developing countries from 1984-1997, they concluded that trade increases income inequality in developing countries but reduces inequality in developed countries. In addition, the authors also pointed out that democracy is inversely correlated with income inequality in developed countries but positively correlated with income inequality in developing countries.

Although most of the existing literature supports the idea that there is a strong link between trade openness and income distribution. However, some have denied the claim that trade openness is correlated with income distribution (see, for example, Ravallion and Jayasuriya, 1988; Glewwe, 1988). In one example, Meschi and Vivarelli (2009) used the GMM estimation, they pointed out that the direction of trade flows is the key element which contributes to income distribution disparity in developing countries rather than trade openness. Their findings also suggested that technology differentials and the skill-based nature of new technologies are the important factors in shaping the distributive effects of trade instead. 


\section{Empirical Model, Methodology and Data}

The empirical specification is aimed at investigating the effect of trade openness on income inequality, and to test the role of institutional quality in the trade openness -income inequality nexus. Thus, the empirical model employed in this analysis was as follows:

$$
\begin{aligned}
\ln I E_{i t}= & \beta_{1 i} \ln I E_{i t-1}+\beta_{2 i} \ln T O_{i t}+\beta_{3} \ln I N S T_{i t} \\
& +\beta_{4 i} \ln I n f_{i t}+\beta_{5 i} \ln E d u_{i t}+\mu_{i}+\eta_{t}+\varepsilon_{i t}
\end{aligned}
$$

Where IEis income inequality (Gini Coefficients), TO is trade openness, INST is institutional quality, Infis inflation, $E d u$ is education and the subscripts $i$ and tindex countries and time, respectively. In addition, the specification also contains an unobserved countryspecific effect $\mu_{i}$, time effect $\eta_{t}$ and error term $\varepsilon$.All variables are in natural logarithm form $(\ln )$. We controlled for inflation because it has been found to increase income inequality. This was observed by Cysneetet al. (2005), Hudson and Namini (2015), Thalassinos et al. (2012) and Maurer and Yesin (2004). In addition, education is also included in the model specification because education has been found to reduce income distribution as shown by Fields (1980), Greenstone et al. (2013) and Vandenbussche andKonings (1998).

This study also incorporates the institutional quality variable as an interactive term to explain its influence on the trade openness - income inequality nexus.

$$
\begin{gathered}
\ln I E_{i t}=\alpha_{0 i}+\beta_{1 i} \ln I E_{i t-1}+\beta_{2 i} \ln T O_{i t}+\beta_{3 i} \ln I N S T_{i t}+\beta_{4 i}\left(\ln T L_{i t} x \ln I N S T_{i t}\right)+ \\
\beta_{5 i} \ln I n f_{i t}+\beta_{6 i} \ln E d u_{i t}+\mu_{i}+\eta_{t}+\varepsilon_{i t}
\end{gathered}
$$

Equations (1) provide the basis for the empirical models estimated in this study. Equations (2) highlight the influence of the institutional quality variable on the trade openness - income inequality nexus.

From Equation (2), the changes inincome inequality due to changes of trade openness can be calculated by examining the partial derivatives of income inequality with respect to trade openness where it depends on the institutional quality variable (INST):

$$
\frac{\partial I E_{i t}}{\partial T L_{i t}}=\beta_{2}+\beta_{3} \ln \left(I N S T_{i t}\right)
$$

To assess whether the institutional quality variable, had a significant effect on the trade openness - income inequality nexus, we computed the standard error of the marginal effect as suggested by Brambor et al. (2006).

\section{Methodology}

The empirical approach used in this study to estimate the equations was based on the dynamic panel GMM estimators as suggested by Arellano and Bond (1991) and further developed by Arellano and Bover (1995). The GMM estimator was selected because of the need to address country-specific effects and simultaneity bias. To explain its application in relation to our datasets, consider the baseline Equation (1). Arellano and Bond (1991) suggested transforming Equation (1) into a first- difference to remove the country-specific effect and using lagged levels of the regressors as instruments to eliminate the simultaneity bias. However, several recent papers have argued that this may lead to incorrect inferences if the explanatory variables are persistent (Arellano and Bover 1995). To overcome this problem, Blundell and Bond (1998) 
proposed a system GMM estimator in which the level and difference equations are combined. The lagged differences of the regressors are then utilised as additional instruments for a level equation. They illustrated that this type of modelling strategy can reduce biases and imprecision linked to the difference estimator.

There are two variants of GMM estimators, the one-step and two-step estimators. Theoretically, the two-step estimator is more efficient because it uses optimal weighting matrices. However, it should be noted that the application of GMM estimators to a sample with small cross-sectional dimensions, may lead to biased standard errors, biased estimated parameters (Windmeijer, 2005), and a weakened over-identification test (Bowsher, 2002). Thus, we reduced the dimensionality of the instrumental variable matrix by restricting the moment conditions to a maximum of two lags on the dependent variables.

This research applied the two-step GMM estimator to examine the impact of trade openness on income inequality and to highlight the role of institutional quality in the trade openness -income inequality nexus. The consistency of the GMM estimator is subject to two specification tests, the Sargan test for over-identifying restrictions and a serial correlation test for disturbances (Arellano and Bond, 1991). Failure to reject the null of the Sargan test would imply that the instruments are valid and the model is correctly specified. With respect to the serial correlation test, one should reject the null of the absence of the first order serial correlation (AR 1) and not reject the absence of the second order serial correlation (AR 2). Where the existence of the second order serial correlation suggests that the original error term is serially correlated. Hence, the proposed instrument variables will be biased and not appropriate.

\section{The Data}

In this study, we averaged the dataset into five-year averages over the period $1984-2012$. The list of countries is presented in Table 1. To portray the trend in income distribution disparity, the Gini Coefficient which is a measure based on the Lorenz curve is being utilised (Gini, 1912). A Gini coefficient of 0 expresses perfect equality, and a coefficient of 1 (or 100\%) expresses maximal inequality among values. Data is taken from the Standardised World Income Inequality Database (SWIID). Trade openness in this study is referred to the sum of exports and imports of goods relative to GDP. The interpretation of the Openness Index is that the higher the index the larger the influence of trade on domestic activities. The trade openness data are obtained from the World Development Indicators (WDI), World Bank.

Institutional quality is measured based on the political risk rating pioneered by Knack and Keefer (1995). The 12 weighted variables of the political risk rating which covers both political and social attributes are: (1) Government Stability, (2) Socioeconomic Conditions, (3) Investment Profile, (4) Internal Conflict, (5) External Conflict, (6) Corruption, (7) Military in Politics, (8) Religious Tensions, (9) Law and Order, (10) Ethnic Tensions, (11) Democratic Accountability, (12) Bureaucracy Quality. Data are taken from the International Country Risk Guide (ICRG). All sub-institutional variables are converted to the same scale namely 10 and the range is from $0-10$. The higher the value indicates a better level of institutional quality.

The importance of human capital through attained education is correlated with economic development, Lucas (1988), Barro (1991) and Simoes et al. (2013). A larger well-educated labour force also implies larger numbers of more skilled workers and a greater ability to absorb advanced technology from developed countries, thus, the level and distribution of educational attainment also have an impact on social outcomes, such as child mortality, fertility, education of children, together with income distribution. Tertiary education attainment of the adult population atage 25 represents the education level attainment in this study, and data is obtained from the Barro and Lee (2013) dataset. As highlighted by Li and Zou (2002), inflation leads to a shift of income from wage earners to profit owners. Thus, indicating that inflation is correlated with income inequality. The inflation data is obtained from the World Development Indicators. 
Table 1. Summary of data set (average five yearly data: $1984-2012 ; \mathrm{N}=65$ )

\begin{tabular}{|c|c|c|c|c|c|c|}
\hline Variable & Source & $\begin{array}{c}\text { Unit of } \\
\text { Measurement }\end{array}$ & Mean & SD & Min & Max \\
\hline $\begin{array}{l}\text { Income } \\
\text { inequality }\end{array}$ & SWIID & Percentile $0-100$ & 37.92 & 9.37 & 19.75 & 0.68 \\
\hline $\begin{array}{l}\text { Trade } \\
\text { openness }\end{array}$ & $\begin{array}{l}\text { World Development Indicators } \\
\text { (WDI) }\end{array}$ & $\%$ of GDP & 83.42 & 54.88 & 14.82 & 430.01 \\
\hline $\begin{array}{l}\text { Institutional } \\
\text { Quality }\end{array}$ & $\begin{array}{l}\text { International Country Risk } \\
\text { Guide (ICRG) }\end{array}$ & Index 0-10 & 6.50 & 2.54 & 0.11 & 10.00 \\
\hline Education & Barro and Lee (2013) & $\begin{array}{c}\% \text { of population } \\
\text { aged } 25 \text { and over) }\end{array}$ & 11.10 & 10.41 & 0.19 & 62.02 \\
\hline Inflation & WDI & $\%$ & 37.27 & 204.26 & 0.01 & 2670.58 \\
\hline
\end{tabular}

Sample countries : Argentina, Australia, Austria, Bangladesh, Belgium, Bolivia, Brazil, Bulgaria, Canada, Chile, China, Colombia, Costa Rica, Denmark, Dominican Republic, Ecuador, Egypt, El Salvador, Finland, France, Germany, Greece, Guatemala, Hong Kong, Hungary, India, Indonesia, Iran, Ireland, Israel, Italy, Japan, Jordan, South Korea, Luxembourg, Malawi, Malaysia, Mexico, Netherland, New Zealand, Norway, Pakistan, Panama, Peru, Philippines, Poland, Portugal, Senegal, Sierra Leone, Singapore, South Africa, Spain, Sri Lanka, Sweden, Switzerland, Taiwan, Thailand, Tunisia, Turkey, Uganda, United Kingdom, United States, Uruguay, Venezuela Zambia.

\section{Empirical Results}

Table 2 presents the empirical results of Equation (1) and Equation (2) using the dynamic panel System GMM approach. Model 1 highlights the estimation result of the Equation (1), whereas Model 2reports the estimate of Equation (2), which examine the marginal effect of institutional quality on the trade openness - income inequality nexus. From Table 2, the lagged dependent variable is statistically significant, which implies that the dynamic GMM is an appropriate estimator and the empirical results can be relied upon for statistical inference.

The findings of Model 1 indicate that the trade openness indicator leads to an increase in income inequality. In terms of other control variables, the empirical results demonstrate that the coefficient of inflation is positive and a statistically significant determinant of income inequality throughout all three models. On the other hand, the coefficient of education is negative and a significant determinant of income equality throughout all models. Nevertheless, the coefficient of institutional quality is negative and a significant determinant of income inequality at conventional levels in. The significant result of institutional quality indicates that, better institutional quality such as effective government, commitment to economic development, functioning parliament, good quality of contract enforcement and investor protection has a corrective effect on income inequality (Chong and Gradstein, 2007).

On the other hand, a conditional hypothesis is introduced in Model 2. Where an interactive term for the measure of the institutional quality factor on the trade openness - income inequality nexus is included. The individual terms of trade openness and institutional quality in the model will not be interpreted as they do not capture the marginal effects of institutional quality in the specification (Brambor et al., 2006). The empirical results indicate that the coefficient of education variable is negative and is a statistically significant determinant of income inequality. In contrast, the coefficient of the inflation variable is positive and is a statistically significant determinant of income inequality.

The marginal effect in Table 2 is evaluated at the mean, minimum and maximum of the institutional quality variable, based on the calculated standard errors (Brambor et al., 2006). As 
shown in Table 3, the marginal effect of institutional quality is a statistically significant determinant of the trade openness - income inequality nexus. The empirical results indicate that the institutional quality variable has a corrective effect in the trade openness - income inequality nexus but only when a threshold level of institutional quality development (mean and maximum) has been attained, where trade liberalisation is associated with lower income inequality level at a higher institutional quality level. Where the coefficients obtained indicates that when institutional quality is attained at mean and maximum level, each additional percentage point of trade openness reduces income inequality by 0.0052 and 0.0257 percentage points respectively.

Overall, the estimated models in Table 2 are relatively well specified with the diagnostic statistics found to be satisfactory. The Sargan test did not reject the over-identification restrictions. As predicted, the null hypothesis of the absence of the first order serial correction (AR 1) was rejected, but the null hypothesis of the absence of the second order serial correction (AR 2) was not.

Table 2. Results of dynamic panel GMM estimations. Dependent variable: Income Inequality Notes: All models are estimated using the Blundell and Bond (1998) dynamic panel system GMM estimations. Figures in parenthesis are standard errors, except for Sargan test and

\begin{tabular}{|c|c|c|}
\hline Variables & Model (1) & Model (2) \\
\hline Income Inequality ${ }_{\text {it-1 }}$ & $\begin{array}{c}0.598 * * * \\
(0.097)\end{array}$ & $\begin{array}{c}0.596 * * * \\
(0.097)\end{array}$ \\
\hline Education $_{\mathrm{it}}$ & $\begin{array}{c}-0.037 * * * \\
(0.007)\end{array}$ & $\begin{array}{c}-0.037 * * * \\
(0.007)\end{array}$ \\
\hline Inflation $_{\text {it }}$ & $\begin{array}{c}0.004 * * \\
(0.002)\end{array}$ & $\begin{array}{c}0.004 * * \\
(0.002)\end{array}$ \\
\hline Trade openness $(\mathrm{TO})_{\text {it }}$ & $\begin{array}{l}0.027 * * * \\
(0.009)\end{array}$ & $\begin{array}{l}0.035 * * * \\
(0.012)\end{array}$ \\
\hline Institutional Quality $_{i t}$ & $\begin{array}{c}-0.043 * * \\
(0.022)\end{array}$ & $\begin{array}{l}-0.078 \\
(0.076)\end{array}$ \\
\hline $\begin{array}{l}\text { Trade openness }(\mathrm{TO})_{\text {it }} \mathrm{x} \\
\text { Institutional Quality }_{\mathrm{it}}\end{array}$ & & $\begin{array}{c}0.017 \\
(0.017)\end{array}$ \\
\hline Constant & $\begin{array}{c}1.395 * * * \\
(0.349)\end{array}$ & $\begin{array}{c}1.370^{* * *} \\
(0.357)\end{array}$ \\
\hline Sargan & $\begin{array}{c}8.786 \\
{[0.7889]}\end{array}$ & $\begin{array}{c}6.345 \\
{[0.785]}\end{array}$ \\
\hline $\mathrm{AR}(1)$ & $\begin{array}{l}-1.737 * \\
{[0.082]}\end{array}$ & $\begin{array}{l}-1.916 * \\
{[0.055]}\end{array}$ \\
\hline AR (2) & $\begin{array}{l}-0.413 \\
{[0.679]}\end{array}$ & $\begin{array}{l}-0.433 \\
{[0.665]}\end{array}$ \\
\hline Observations & 323 & 323 \\
\hline Number of Instrument & 16 & 17 \\
\hline Number of Country & 65 & 65 \\
\hline
\end{tabular}


Table 3. Marginal Effect of Institutional Quality on Trade Openness - Income Inequality nexus

Model (3)

\begin{tabular}{ll}
\hline Minimum & $0.293^{*}$ \\
Mean & $(0.168)$ \\
& $-0.005^{*}$ \\
Maximum & $(0.003)$ \\
& $-0.026^{*}$ \\
& $(0.015)$
\end{tabular}

Note: *, ** and *** indicate the significant levels at 10\%, 5\% and 1\%, respectively. Figures in parenthesis are standard errorswhich are calculated based on Brambor et al. (2006). The marginal effects are based on the results of Twostep System GMM indicated in Table 3.

\section{Robustness Check}

Table 4 presents the empirical results with an alternative source of income inequality data from the Estimated Household Income Inequality Data Set (EHII), University of Texas. However, due to the fact that the income inequality datasets are more comprehensive in cross-country data, the cross-sectional analysis is conducted. The coefficient for trade openness is positive and a statistically significant determinant of income inequality. In addition, institutional quality variable is significantly associated with income inequality but the coefficient of the education variable is an insignificant determinant of income inequality.

Table 5 presents the empirical results of heteroskedasticity-robust standard errors of Equation (1) and (2). The results obtained is consistent with Table 2, hence suggests that the standard errors estimated are independent and identically distributed.

Table 4. Robustness Check to Alternative Income Inequality Data (Cross-Country) Dependent variable: Income Inequality

\begin{tabular}{lc}
\hline Variables & Model (4) \\
\hline Trade Openness & $0.050^{* *}$ \\
& $(0.025)$ \\
Inflation & $0.152^{*}$ \\
& $(0.091)$ \\
Education & -0.025 \\
& $(0.032)$ \\
Institutional Quality & $-0.381^{*}$ \\
Constant & $(0.218)$ \\
& $3.634^{* * *}$ \\
Observations & $(0.148)$ \\
R-squared & 55 \\
\end{tabular}

Notes: Figures in parenthesis are standard errors. ${ }^{*}, * *$ and $* * *$ denote significant at $10 \%, 5 \%$ and $1 \%$, respectively. 
Table 5. Results of dynamic panel GMM estimations robust.

\begin{tabular}{|c|c|c|}
\hline Variables & Model (1) & Model (2) \\
\hline Income Inequality $y_{\mathrm{it}-1}$ & $\begin{array}{c}0.598 * * * \\
(0.142)\end{array}$ & $\begin{array}{c}0.596^{* * * *} \\
(0.140)\end{array}$ \\
\hline Education $_{\text {it }}$ & $\begin{array}{c}-0.037 * * * \\
(0.007)\end{array}$ & $\begin{array}{c}-0.037 * * * \\
(0.007)\end{array}$ \\
\hline Inflation $_{\text {it }}$ & $\begin{array}{l}0.004^{*} \\
(0.003)\end{array}$ & $\begin{array}{l}0.004^{*} \\
(0.003)\end{array}$ \\
\hline Trade openness $(\mathrm{TO})_{\mathrm{it}}$ & $\begin{array}{c}0.0273 * * \\
(0.012)\end{array}$ & $\begin{array}{c}0.035^{* *} \\
(0.015)\end{array}$ \\
\hline Institutional Quality $_{i t}$ & $\begin{array}{c}-0.043 * * \\
(0.002)\end{array}$ & $\begin{array}{l}-0.077 \\
(0.073)\end{array}$ \\
\hline $\begin{array}{l}\text { Trade openness (TO) })_{i t} \mathrm{X} \\
\text { Institutional Quality }\end{array}$ & & $\begin{array}{c}0.017 \\
(0.016)\end{array}$ \\
\hline Constant & $\begin{array}{c}1.395 * * * \\
(0.505)\end{array}$ & $\begin{array}{c}1.370 * * * \\
(0.505)\end{array}$ \\
\hline $\mathrm{AR}(1)$ & $\begin{array}{l}-1.672 * \\
{[0.094]}\end{array}$ & $\begin{array}{l}-1.676^{*} \\
{[0.094]}\end{array}$ \\
\hline AR (2) & $\begin{array}{l}-0.464 \\
{[0.643]}\end{array}$ & $\begin{array}{c}-0.429 \\
{[0.668]}\end{array}$ \\
\hline Observations & 323 & 323 \\
\hline Number of Instrument & 16 & 17 \\
\hline Number of Country & 65 & 65 \\
\hline
\end{tabular}

Dependent variable: Income Inequality

Notes: All models are estimated using the Blundell and Bond (1998) dynamic panel system GMM estimations. Figures in parenthesis are standard errors, except for Arellano-Bond test for serial correlation, which are p-values. *, ** and $* * *$ indicate the significant levels at $10 \%, 5 \%$ and $1 \%$, respectively.

\section{Conclusion}

According to the World Economic Forum, rising income inequality and the polarisation of societies pose a risk to the global economy and may lead to increased polarisation and a lack of political stability. The United Nations Development Programmes (UNDP) reported in 1999 that the top fifth of the world's people in the richest countries enjoy 82 percent of the export trade. Hence, signifyingthat trade promotes economic integration but saying nothing about income distribution parities. The results of this study contribute to the unresolved debate on the significance of trade openness on income inequality in the existing literature. Secondly, this study highlights the role of the institutional quality variable in the trade openness - income inequality nexus.

Based on the empirical results obtained using the system GMM estimator, the empirical results suggested that trade openness significantly increases income inequality. In addition, the institutional quality variable is negative and statistically significantly associated with a lower income inequality level. Thus, suggesting that policies to improve the level of institutional quality should be a priority. The education indicator is negative and statistically significantlycorrelated with income inequality, which indicates that human capital development reducesincome distribution disparities through reducing the income gap between skilled and low-skill workers.

The marginal effect also demonstrated a significant result, which revealed that institutional quality has a corrective effect on the trade openness - income inequality nexus but only when a 
threshold level of institutional quality development has been attained. The empirical results suggest that further improvement of institutional quality above the threshold will decrease income distribution parities. Hence, policy makers would be advised to pursue policies to improve the institutional quality level prior to any trade openness negotiations. Similarly, policies to increase the quality of education to increase the supply of skilled labour should be put forward.

\section{References}

Ackah, C. (2007). Trade reforms, human capital and poverty: A Pseudo-panel analysis for Ghana. Centre for Research in Economic Development and International Trade, School of Economics, University of Nottingham.

Agenor, P. R. (2004). Does globalisation hurt the poor? International Economics and Economic Policy. 1(1), 21-51.

Aradhyula, S., Rahman, T., \& Seenivasan, K. (2007). "Impact of international trade on income and income inequality", paper presented at American Agricultural Economics Association Annual Meeting, Portland.

Arrellano, M., \& Bond, S. (1991). Some tests of specification for panel data: Monte Carlo evidence and an application to employment equations. Review of Economics Studies, 58, 277 297

Arellano, M., \& Bover, M. (1995). Another look at the instrumental variable estimation of errorcomponents models. Journal of Econometrics, 68, 29-51.

Barro, R. J. (1991). Economic growth in a cross-section of countries. Quarterly Journal of Economics, 106, 407-443.

Blundell, R., \& Bond, S. (1998). Initial conditions and moment restrictions in dynamic panel data model. Journal of Econometrics, 87, 115-143.

Afonso, O., \& Gil, P, M. (2013). Effects of north-south trade on wage inequality and on humancapital accumulation. Economic Modelling, 35, 481-492.

Borras, Jr., S., M. (2007) 'Free market', export-led development strategy and its impact on rural livelihoods, poverty and inequality: The Philippine experience seen from a Southeast Asian perspective. Review of International Political Economy, 14(1), 143-175.

Brambor, T., Clark,W., R. \& Golder, M. (2006). Understanding interaction models: Improving empirical analyses. Political Analysis, 14, 63-82.

Bowsher (2002)

Carneiro, F. G., \& Arbache, J. S. (2003). Assessing the impacts of trade on poverty and inequality. Applied Economics Letters, 10(15), 989-994.

Chong, A., \& Gradstein, M. (2007). Inequality and institutions. The Review of Economics and Statistics, 89(3), 454-465.

Cysne, R. P., Maldonado, W. L., \& Monteiro, P. K. (2005). Inflation and income inequality: A shopping-time approach. Journal of Development Economics. 78(2), 516-528.

Kutlina-Dimitrova, Z., \& Lakatos, C. (2014). Assesing the economic impacts of EU-Singapore FTA with a dynamic general equilibrium model. International Economics and Economy

Policy. 11(3). 277-291. 
Dollar, D., \& Kraay, A. (2004). Trade, growth and poverty. The Economic Journal, 114, 22-49.

Dutt, A. K., \& Mukhopadhyay, K. (2005). Globalisation and the inequality among nations: A VAR approach. Economics Letters, 88(3), 295-299.

Fields, G. S. (1980). Education and income distribution in developing countries: A review of the literature. The World Bank, 231-315.

Glewwe, P.(1988). Economic liberalisation and income inequality. Journal of Development Economics, 28, 233-246.

Greenstone, M., Looney, A., Patashnik, J., \& Yu, M. (2013). Thirteen economic facts about social mobility and the role of education. The Hamilton Project.

Hudson, D., \& Namini, S. S. (2015). Inflation and income inequality in developed and developing countries. Conference Paper Published by ResearchGate https://www.researchgate.net/publication/301489978.

Knack, S., \& Keefer, P. (1995). Institutions and economic performance: Cross-country tests using alternative institutional measures. Economic and Politics, 7, 207-27.

Li, H., \& Zou, H. F. (2002). Inflation, growth and income distribution: A cross country study. Annals of Economics and Finance, 3, 85-101.

Lucas, R. E. (1988). On the mechanics of economic development. Journal of Monetary Economics, 22, 3-42.

Mah, J., S. (2003). A note on globalisation and income distribution--The case of Korea, 19751995. Journal of Asian Economics, 14(1), 157-164.

Mah, J., S. (2013). Globalisation, decentralisation and income inequality: The case of China. Economic Modelling, 31, 653-658.

Meschi, E., \& Vivarelli, M. (2009). Trade and income inequality in developing countries. Journal of World Development, 37, No.2, 287-302

Mohammad, S. (1981). Trade, growth and income redistribution. Journal of Development Economic, 9, 131-147.

Muarer, M. R., \& Yesin, P. A. (2004). Income inequality and inflation. Working paper for conference in Luca.

North, D, C. (1991). Institutions. Journal of Economic Perspectives, 5, 97-112.

Ravallion, M., \& Jayasuriya, S. (1988). Liberalisation and inequality in Sri Lanka. Journal of Development Economics, 28, 247-255.

Roses, J. R., Galarraga, J. M., \& Torado, D. A. (2010). The upswing of regional income inequality in Spain (1860-1930). Explorations in Economic History, 47(2), 244-257.

Savvides, A. (1998). Trade policy and income inequality: New evidence. Economic Letters, 61(3), 365-372.

Simoes, M.C.N., Andrade, J.A.S., \& Duarte, A.P.S. (2013). A regional perspective on inequality and growth in Portugal using panel cointegration analysis. International Economics and Economy Policy. 10(3), 427-451. 
Stolper, W. F., \& Samuelson, P. A. (1941). Protective and real wages. The review of Economies Studies, 9(1), 58-73.

Thalassinos, E., Ugurlu, E., \& Muratoglu, Y. (2012). Income inequality and inflation in the EU. European Research Studies. XV(1), 127-140.

UNCTAD. (1994). The outcome of the Uruguay round: An initial assessment. United Nations Conference on Trade and Development, Trade and Development Report, Geneva, Switzerland.

UNCTAD. (2012). Trade, income distribution and poverty in developing countries: A survey. United Nations Conference on Trade and Development, Trade and Development Report, Geneva, Switzerland.

UNDP. (1999). Globalization with a human face. Human Development Report. New York: Oxford University Press.

Vandenbussche, H., \& Konings, J. (1998).Globalisation and the effects of national versus international competition on the labour market: Theory and evidence from Belgian firm level data. The World Economy, 21(8), 1151-1177.r

Wade, R. H. (2004). Is globalisation reducing poverty and inequality? World Development, $32(4), 567-589$.

Windmeijer, F. (2005). A finite sample correction for the variance of linear efficient two-step GMM estimators. Journal of Econometrics, 126(1), 25-51.

WTO. (2007). Trade liberalisation and development - WTO and the Doha Round. World Trade Organisation (WTO), Geneva, Switzerland. 